\title{
Message of the President of the Brazilian League of Epilepsy
}

E m fevereiro de 2007 ocorrerá em São Paulo a Primeira Escola Latinoamericana de Verão de E Epilepsia. Este evento é uma iniciativa da "International League Against Epilepsy - Educational Program”, com o apoio da Liga Brasileira de Epilepsia. O programa é coordenado pelo Prof. Esper Cavalheiro e contará com diversos professores da América Latina, EUA e Europa. Esta "Escola de Verão" abrangerá de forma concentrada os principais tópicos da epileptologia, além de atualização de aspectos conceituais e práticos, incluindo modelos experimentais, diagnóstico e tratamento. O curso, destinado a estudantes e profissionais latino-americanos com interesse em epileptologia básica ou clínica, será sem dúvida uma oportunidade ímpar para que jovens pesquisadores latino-americanos possam ampliar seus conhecimentos e interagir com professores que são referências internacionais nos diversos aspectos da epileptologia.

Aproveito para desejar aos leitores um feliz ano novo, cheio de realizações e progressos.

Fernando Cendes

Presidente 